\title{
Notes on the Established-Outsiders Figuration: A Psychoanalytical Approach
}

\author{
André Oliveira Costa \\ University of São Paulo (USP), São Paulo, Brazil \\ The São Paulo Research Foundation (FAPESP-2015/0489-7), São Paulo, Brazil
}

\begin{abstract}
The influence of psychoanalysis in the work of sociologist, Norbert Elias is notorious and recognized by himself. The established and the outsider figuration show how individuals are in relationships of interdependence with each other, allowing the dissolution of the antithesis between individual and society. In this paper, we propose to consider how the concept of figuration can contribute as an operator for the field of psychoanalytic practice. So, we will seek to articulate psychoanalysis and Norbert Elias's sociology through the concept of figuration, as a methodological operator that helps us understand the subjective processes in psychoanalytic practice.
\end{abstract}

Keywords: psychoanalysis, figuration, established and outsiders

\section{Introduction}

When a psychoanalyst has an appointment with a patient in his/her consulting room, he cannot fail to listen to the specific details of suffering, anxiety, and psychological symptoms without taking into consideration the relevant historical, political, and social circumstances. A patient seeking psychological treatment reproduces the discourses of the society, which he/she is part of and consequently reveals, and in a unique way, the problems of the social groups to which he/she belongs. The shift from macro- to microanalysis is an attempt to problematize psychoanalytical practice, bearing in mind that what patients say is permeated by the logic of the configuration between established groups and outsiders.

The issues relate to the problem of the relationship between the individual and society, and lie at the heart of the thinking of Norbert Elias and also of Sigmund Freud. The influence of Sigmund Freud's psychoanalysis on the work of Norbert Elias is well known and was recognized by the sociologist himself, as can be seen in an interview with the French newspaper Libération, "Without Freud, I would not have been able to write what I wrote. His theory was essential for my work and all his concepts (ego, super-ego, libido, etc.) are familiar to me" (Elias, 2000, p. 93). Instead of thinking of the individual as an autonomous being, whose structure is independent and isolated from objects and the context which it forms part of, separated by an invisible wall from his/her own body, from other people and from society, namely, ahomo clausus, Elias proposes that we think of the individual as 'an 'open personality,' which possesses a greater or lesser degree of autonomy (but never absolute or total autonomy) in relation to that of other people, and which, in reality, throughout his/her

André Oliveira Costa, Psychoanalyst, Ph.D. in Education at Federal University of Rio Grande do Sul (UFRGS), Postdoctorant at Faculdade de Filosofia, Letras e Ciências Humanas, University of São Paulo (FFLCH-USP); The São Paulo Research Foundation (FAPESP-2015/0489-7). 
entire life is fundamentally geared towards other people and is dependent on them" (Elias, 2012, p. 132). In the same way, societies should also be thought of as structures that are "always more or less incomplete: from wherever they are looked at, they continue to be open in the temporal sphere towards the past and the future" (Elias, 2011, p. 65).

The following questions constitute the point of departure for the subsequent discussion: how do configurations between established groups and outsiders affect the specific symptoms of each individual? What can each individual do with the discourse that his/her group passes on to him/her? Psychoanalytical treatment is a clinical tool that enables the individual to deconstruct the cause of his suffering and to rebuild new configurations for his/her life. By expressing himself/herself, the patient gradually writes his/her own biography and he/she transforms aspects of his/her past that are being repeated in the present so that they can be re-inscribed as new configurations in the future.

\section{The Established-Outsiders Configuration}

Norbert Elias, throughout his work, researched the connection between individual and society, and did not restrict himself to thinking about these terms as if they were totally separate from each other. In his book The Established and the Outsiders, he investigated the social symptoms of a small English town. The residents of this community did not differ from each other in terms of nationality, ethnic origin, color, or race, nor in terms of their type of profession, income, or educational level. The only difference between them was that one group of residents was made up of long-standing inhabitants, whose families had lived in the region for two or three generations, and the other group was made up of recent arrivals.

The difference in the amount of time that the two groups of inhabitants had lived in this English town was enough to establish a division between the two groups: the established and the outsiders. Elias and Scotson (1994) described the relationships between them as follows. The members of the established group felt superior, more powerful, more human, and better than the others. The established group had a high level of cohesion, a differential integration that enabled them to control power. In addition, they had privileges and social status, they felt better, and they had more charisma and pride in their self-image. Their lives were in accordance with the norms, rites, and ceremonies established by other generations, which were passed on like a tradition that nothing could break. The established group succeeded in reserving for its own members the best positions within the town's social institutions: the local council, schools, and social club. Furthermore, they excluded members of the group of outsiders from these organizations. But what led people to form two groups and to position themselves as better than and superior to other human beings? What allowed them to create stigmas about the others as if the latter were people of lesser value?

The established group excluded all members of the group of outsiders from social contact, making it taboo to mix with them. This exclusion allowed the established group to preserve their identity as superior beings. Members of the group of outsiders, on the other hand, were stigmatized as inferior beings that belonged to a group that lacked cohesion and honor. They were seen as unable to follow norms, and thus, were deemed vandals, hooligans, and uncivilized. The outsiders were supposedly endangering the tradition of the established group, threatening the latter's deep-rooted defenses against disrespect for norms, and disturbing the guarantees of the group's taboos. The outsiders are seen as threatening to disrupt the social position of each member of the established group, as harming the latter's self-respect, their pride, and their identity as superior beings. But why are they stigmatized in this way? What does this tell us about the structure of the dominant group? 
The image that each person has of his/her group and of his/her own place within it influences the image that he/she has of himself/herself. All those who belong to the established group must pay a price. Superiority, powers, privileges, and charisma are the reward for acquiescing to the specific norms of the established group, and to the limitations in terms of the positions that they can occupy and the relationships that they can form. This price is paid by each individual who allows his/her emotions and behavior to be controlled, obeying the tradition that is passed on to him/her by his/her family members and the group to which he/she belongs. The satisfaction that each person derives from being part of the group is an attempt to compensate for the sacrifice in terms of personal satisfaction caused by surrendering to the group's norms.

The group ideal of "we" is akin to the individual's ideal of "ego" (Elias \& Scotson, 1994). The self-control that the established group imposes on itself is linked to the internal opinion that it has of itself. Belonging to a particular established group makes its members feel that they have greater value as human beings than the outsiders. The fantasies and ideals that a person has in relation to himself/herself cannot be separated from the collective fantasies and ideals of the group he/she belongs to.

\section{The Concept Society for Freud and Elias}

For Elias, society is formed from the network of functional interdependence that individuals establish between themselves. Each individual emerges from a context of "invisible bonds," a network of relationships predating their birth that "is not something that exists outside individuals either" (Elias, 2011, p. 45), in so far as they are functions of dependence that each person exercises on other people. These bonds form a network within each individual that can circulate in a limited way, capable of being transferred only for functions previously determined by the structure of relationships within which he/she is inserted.

In the text The Freudian Concept of Society and Beyond, Elias (2010a) stated that Freud was not capable of understanding societies as such, in so far as the Freudian perspective on the social existence of human beings is fundamentally based, in Elias's view, on the centrality of the individual. Elias recognized that Freud did not deny the importance of the other nor of social aspects for the formation of the psyche. However, in the opinion of the sociologist Elias, Freud represented society in an atomistic way and the various elements of the psychic apparatus (ego, super-ego, and id) as static objects. Social and psychological processes are two aspects that do not connect in psychoanalytical theory, according to the reading of Elias.

Incapable of establishing a connection between the individual and society that went beyond the antinomy between his terms - Freud, Elias stated, "conceived of a model of the eminently sociological individual and a model of the eminently individualistic society" (Elias, 2010a, p. 137). To put it another way, the individual presents himself/herself as a complex of identifications with others, "a society in miniature," and society proves to be an atomized structure, as exemplified by the masses, which function according to the same logic as psychological processes.

Belonging to the established group can bring economic and social advantages, as well as power and privileges. But it also leads to privations and creates traditions that resist modification and that impede the development of society and its individuals. These are traditions that fix places within families, groups, and society. These collective fantasies, which configure certain groups as if they were ideals of civilization and culture, establish the identities of each individual on the basis of his/her membership of the group, and mark the self-image of each person as if he/she were a superior being, differentiated from all others. The degree of cohesion within the established group has a regulatory and coercive impact on the feelings and behavior of its 
members. Furthermore, a loss of status or contact with an outsider threatens the equilibrium of the group and the fantasy of superiority.

We live in a time when the positions that people occupy within social groups are no longer determined by tradition, nor by the fixity of social positions. We live in a time of great geographical mobility, of toing and froing between economic classes, and of rapid change. Given this context, how can we recreate our place in the world and not sever the links with our ancestors? What are we to do with what has been passed on to us if it is no longer appropriate for us to follow tradition like a strict commandment?

Freud's difficulty in understanding social processes, in the opinion of Elias (2010a), stems from his dedication to therapeutic practice, being interested only in the psychological suffering of individuals. Much Freud stated that every individual psychology is nothing more than a social psychology. However open he was to considering a sociological explanation for the experiences of individuals, he did not take into consideration the "social identity of individuals - the identity of the "we'." This is what, according to Elias, "can express itself in the sense that we are the center of the universe" (Elias, 2010a, p. 139). In Elias's view, the levels of the discourses of a person's "ego" and his/her "we" are interlinked. Psychoanalytical theory, when exclusively focused on the perspective of the "ego," creates an imbalance between the levels of the "ego" and of the "we," which has consequences for people's behavior and feelings.

Norbert Elias (2010b) wrote Mozart: The Sociology of a Genius in order to answer these questions, illustrating how the composer's life was marked by his need to extricate himself from the imperatives of the tradition that his father, Leopold Mozart, tried to pass on to him. For Mozart's father, his prodigious son's life could only make sense when he took up the position of official court musician. However, for Mozart himself, his life would not have made sense if it had been devoted to composing music in accordance with the tastes and the wishes of an established group drawn from the aristocracy. Mozart wanted to express his feelings, emotions, and fantasies via his own compositions. In order to do so, he would have to evade the coercion of the ideals that were imposing themselves on him and break down the fixity of social positions. Elias (2010b) showed us how art, for Mozart, was a way for him to progress down previously uncharted routes. He pursued new experiences, inventiveness, and spontaneity. Art situated Mozart as an outsider and enabled him to create a unique compositional style.

In the text Family Romances, Freud writes, "The liberation of an individual from the authority of his/her parents is one of the most necessary though one of the most painful results brought about by the course of his/her development" (2003a, p. 69). The break that the individual makes with his/her family may also be displaced on to a break with wider social groups. Freud continues, "Indeed, the whole progress of society rests upon the opposition between successive generations" (2003a, p. 69). The process of civilization, as well as the development of individuals, is achieved via small-scale ruptures, whereby an individual distances himself from the coercion enforced by the established group, or breaks the repetitive cycle of psychological symptoms. In this way, new configurations are produced by the transformations and changes in the relationships between individuals.

The idea of the unconscious described by Freud enables us to understand that individuals can no longer be considered to be autonomous and independent, "masters in their own home" (2010, p. 184). With regard to the unconscious, we always speak from a place where we do not recognize ourselves. Our words are marked by the discourses of other people, especially those who passed on a place in the world. In The Ego and the Id, Freud (2003b) stated that the ego is marked by the history of identifications with others. When a patient appears in a 
consulting room seeking psychoanalytical treatment, it is because something is not going well in his/her life. Something relating to the discourse of others, which provides him/her with his/her place in the world, is no longer in tune with his/her own desires, and his/her own specific actions. The direction of the patient's treatment sought first an understanding of the causes of his/her psychic symptoms, their relationship to social problems, including family relationships. Psychoanalytic treatments do not seek to adapt the patient to society. It was possible to bring relief to the patient's symptoms through speech. The patient could understand that he/she does not have to be subject to the standards that are imposed by society, since this does not mean normality or pathology, nor belonging or exclusion. The patient can re-signify his/her social place by subjectively shifting from the position of outsider that is imposed by society to those who do not conform to their demands.

In the text Das Unheimlich, which is translated into English as The Uncanny, but whose meanings vary from "strange" and "familiar," to "friendly" and "weird" (Freud, 2003c), Freud says that the unconscious is something that ought to be hidden, but which has come to light. What is most intimate and familiar to us proves to be the most strange and alien to our consciousness. The unconscious manifests itself in different ways: via a particular symptom, dreams, jokes, and slips of the tongue. In all these situations, the unconscious reveals itself to be another discourse, to put it another way, or to be the discourse of the other. The unconscious proves itself to be a foreign body, which trespasses on our consciousness and undermines our certainties.

What is of particular interest here with regard to Freud's text is how we think about the logic of the relationship between conscious and unconscious elements. What we are dealing with here is not a binary logic, which separates and isolates the two psychological constructs as if each were independent of the other. The unconscious elements exist as a continuation of consciousness, as we can see in the design of the Möbius strip by Maurice Escher (1969). As we can see Figure 1, the ants are marching along surfaces that, if viewed at a particular instance, seem to be in opposition to each other, but when seen from a long-term perspective, are surfaces that in fact prove to be a continuation of each other.

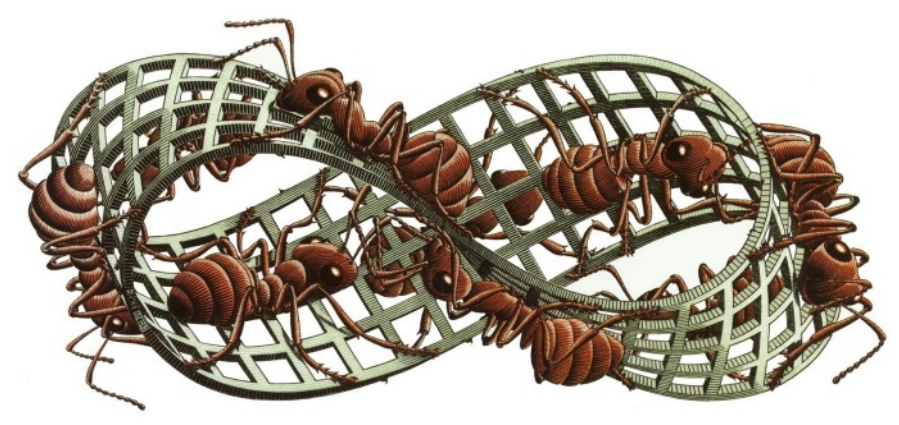

Figure 1. Möbius Strip II.

Just as with the unconscious and conscious, we should think of the individual and the groups to which he belongs as being related to each other as part of a continuum. We are dealing with a structure that articulates itself on the basis of that which sets itself in opposition to it. In the same way, established groups are formed on the basis of their relationship with outsiders - a relationship that, at a given moment, is marked by exclusion, but which must be thought of as being part of a continuum. In this sense, outsiders determine the boundaries of the established group, and they are the inverse of the established group, the exception that proves the rule. The outsiders reveal a truth that the established do not want to acknowledge. 


\section{Conclusions}

Norbert Elias recognizes that the history of humanity, the history of a society, and the history of an individual are closely connected. Elias says, "They are always determined, finally, by the history and the actual structure of his/her relations to other people, by the structure of society and they change with it" (Elias, 2012, p. 485). The structure of people's feelings depends upon the levels of social structures. What we know about life, our knowledge, our feelings, and the way we construct our bonds are based in "love-and-learn relationships" and in "love-and-learn" processes (Elias, 1987).

A brief account of a psychoanalytical case study helps us to understand the clinical effects of the established and outsider's configurations. It involves a female patient in Brazil around aged 30, who is facing subjective issues relating to her new professional status. This patient, besides being a person of color, comes from a low-income family and her parents have no formal education. In order to study at a public university, she benefitted from an incentive introduced by Brazil's education policy that makes a certain number of places available in public universities, as well as scholarships for private universities, for students from low-income families, of black or indigenous descent, and who have come from state schools. As a result of her new social position, this patient has ended up severing ties with the social and family environment where she grew up.

The women's emancipation was followed by their sexual emancipation. According to Cas Wouters, parents of different social classes came to take more account of the interests and feelings of their children, included their sexuality. Only since the sexual revolution that women have actively taken part in the public life, in their sexual desires and how to get more "satisfactory lust-balance - the balance between longings for sexual gratification and for enduring relational intimacy" (2016, p. 9). However, the psychoanalysis shows us that the originals desires and drives of the children, their sexuality, and their bodily needs remains during the adult life, while Norbert Elias (2012) indicated that sexuality and corporality are set apart and the adults have to learn how to balance between been a sexual subject and a sexual object. "In the process of sexualisation and eroticisation, especially since the Sexual Revolution, women collectively have come into a position similar to that of young people when becoming sexually mature: both entered the trial and error process of becoming more of a sexual subject" (Wouters, 2016).

However, Freud was very conscious of the alterations in the psychological economy of individuals who moved from one social structure to another. In Civilized Sexual Morality and Modern Nervousness, for example, he wrote, "For most people, there is a limit beyond which their constitution cannot comply with the demands of civilization. All who wish to reach a higher standard than their constitution will allow, fall victims to neurosis. It would have been better for them if they could have remained less 'perfect'." (Freud, 2003d, p. 1987). And in Family Romances, he wrote, "the whole progress of society rests upon the opposition between successive generations. On the other hand, there is a class of neurotics whose condition is recognizably determined by their having failed in this task" (Freud, 2003a, p. 243).

This patient has to contend with being distanced from her family because her salary is much higher than that of her parents, who did not have the same professional opportunities. She is also suffering from a loss of romantic relationships as a result of racial issues. The men who belong to her new social class, the majority of whom are white, reject her for being black, and the men she feels attracted to do not get involved with her because they feel inferior as a consequence of her economic class. Sexualisation and eroticization processes are accelerating, and according to Wouters (2016), women advance their accentuating attractiveness as they 
continue to come into sexual subjects, breaking the barriers with the traditional forms of societies.

The incompatibilities of no longer belonging to her social group and of not recognizing herself in the new group to which she belongs, are manifesting themselves as symptoms of shame and guilty. Those feelings transgress the boundaries of social process and psychological process. As Goudsblom (2006) said,

In any case, shame is more than almost any other emotion an exclusively social emotion. It arises in social interaction. And it functions in social interaction, even if the person who is ashamed is not aware of either the social origins or the social meanings of his/her shame.

This patient arrived at the office questioning her place in the world, creating for herself obstacles that are hindering her personal development and devaluing her professional capabilities and her status as a woman. What with have to deal with in a psychoanalytical treatment are her difficulties to keep herself in a place of helplessness, as an outsider, as what are her possibilities to reorganize herself on the basis of a frame of reference within which she cannot recognize herself.

\section{References}

Elias, N. (1987). On human beings and their emotions: A process-sociological essay in essays III on Sociology and the humanities. (Vol. 16). Dublin: UCD Press.

Elias, N. (2000). Norbert Elias ou la sociologie des continuities (Norbert Elias or the sociology of continuous). Retrieved from http://labyrinthe.revues.org/273

Elias, N. (2010a). Le concept Freudian de sociétéetau-delà (The Freudian concept of society and beyond it). Paris: La Découverte.

Elias, N. (2010b). Mozart: The sociology of a genius in Mozart and other essays on courtly art (Vol. 12). Dublin: UCD Press.

Elias, N. (2011). The society of individuals (Vol. 3). Dublin: UCD Press.

Elias, N. (2012). On the process of civilization: Sociogenetic and psychogenetic investigations (Vol. 3). Dublin: UCD Press.

Elias, N., \& Scotson, J. (1994). The established and the outsiders (Vol. 4). Dublin: UCD Press.

Escher, M. (1969). Moebius Strip II. Retrieved from http://www.mcescher.com/gallery/recognition-success/mobius-strip-ii/

Freud, S. (2003a). Sigmund: La novela familiar del neurotic (Family romance) (Vol. 2). Madrid: Biblioteca Nueva.

Freud, S. (2003b). El yo y el ello (The Ego and the Id) (Vol. 3). Madrid: Biblioteca Nueva.

Freud, S. (2003c). Lo ominoso (The unncany) (Vol. 3). Madrid: Biblioteca Nueva.

Freud, S. (2003d). La moral sexual "cultural" y la nervosidadmoderna (Civilized sexual morality and modern nervous illness) (Vol. 2). Madrid: Biblioteca Nueva.

Freud, S. (2010). Uma dificuldade da psicanálise (One of the difficulties of psychoanalysis). São Paulo: Companhia da Letras.

Goudsblom, J. (2016). Shame as social pain. Retrieved from http://hdl.handle.net/2027/spo.11217607.0005.104

Wouters, C. (2016). Towards an integration of lust and love? Eroticisation and sexualisation since the 1880s. Retrieved from http://hdl.handle.net/2027/spo.11217607.0005.105 